International Journal of Arts and Humanities

ISSN: 2581-3102

Volume: 04, Issue: 06 "June 2020"

\title{
THE OMANI EMPIRE AND THE DEVELOPMENT OF EAST AFRICA
}

\author{
${ }^{1}$ NTUI, DANIEL OKORN; ${ }^{2}$ ABOH, JAMES A; ${ }^{3}$ PATRICK O. ODEY \\ ${ }^{1}$ INEC, Akwa Ibom State \\ ${ }^{2}$ Department of History and International Studies, \\ University of Calabar, Calabar. \\ ${ }^{3}$ Department of History and International Studies, \\ University of Calabar, Calabar
}

\begin{abstract}
The East African coast had extensive interaction with other regions and races in the world. One of these groups was the Omani Arabs who were pulled to the coastline of East Africa for commercial expansion, the serenity of the environment and the fertility of the soil. The Omani Sultan had ruled the empire from Muscat but later relocated the capital to Zanzibar. This paper relied on secondary sources to examine the impact of the Omani Empire on the economic, sociocultural and political development of East Africa. It was observed that with the interactions that first began along the coastlines of East Africa some coastal city-states like Pemba, Malindi, Mozambique, Sofia, Kilwa, Mombasa, and Zanzibar emerged. The Omani Arabs under the leadership of Sultan Sayyid Said introduced the caravan trade, custom duties, credit facility for investment, and the invention of a hybrid of language and culture- Swahili/Kswahili. Nevertheless, the innovations introduced into the east coast of Africa were intended to fulfill the commercial mandate of the Arabs leaving Africans as passive and/or unequal participants in the scheme of things, given the meddlesomeness of the Arabs in the internal affairs of the East Africans leading to conflicts that continue to hunt the region.
\end{abstract}

Keywords: Arabs, Oman, Sayyid Said, Swahili, Zanzibar

\section{INTRODUCTION}

Africa, like China, was not well known to the outside world before the nineteenth century, and information about the interior was the product of occasional visits from hardy travelers, such as Ibn Battuta- the Marco Polo of the tropics. However, the assumption that the continent was also isolated from external contacts, though it has served a useful purpose here in focusing attention on internal checks on the development of the market, is historically inaccurate and must now be discarded (Hopkins 78). A. G. Hopkins' remark on the scanty knowledge of Africa by the 
International Journal of Arts and Humanities

ISSN: 2581-3102

Volume: 04, Issue: 06 "June 2020"

outside world stems from the fact that inroads into the interior was gradual since interactions with these external contacts were rather restricted to the coastal areas at the time.

Geographically and historically speaking, East Africa was not terra incognita before Arabic incursion. There were indigenous people who inhabited the area mainly the interior. The Cushites from the north-west settled along the northern fringes of the coast and southern Mogadishu (Somalia), while Africans from the southern fringes of the East coast were the Bantus, who settled along the riverine areas because of their agrarian activities (Imbua, Onor and Odey 92).

The East African coast is an interface between the continent of Africa and the Indian Ocean evidently linked by the Monsoon Winds. Abdul Sheriff further describes the area as one being, "inhabited by a littoral society that was best placed to play a leading role in economic, social and cultural interaction, including intermarriage, between two worlds" (oxfordre.com).

The East African coastal area was opened to the outside world- for instance, the Arabs and the Indians due majorly to their geographical location and meteorological ingenuity of the Arabian traders who traversed to and fro the Indian Ocean aided by the north-east and south-west Monsoon Winds from December to February and April to September respectively. The earliest Arabic presence in the East African coast was possible as a result of migratory dissident Muslims from Arabia. Thus, their presence began the spread of Islam in the area. And by the $19^{\text {th }}$ century, the East African coast was under the Sultanate of Oman superintendent from Muscat, Oman's capital at the time.

\section{THE RISE OF SULTAN SAYYID SAID IN EAST AFRICA}

The Omani commercial Prince, Sayyid Said (1790-1856), alsp known as Said Ibn Sultan was a famous Arabian personality in the history of East Africa. He ruled Zanzibar and Oman from 1806-1856. This period was shared- 30 years of his reign was in Muscat and the rest was in Zanzibar. He was a pious man of the Ibadhism-Islamic sect. This is a peaceful and tolerant Islamic sect that advocated the return of Islam to its original state, with emphasis on "good personal conduct, strong spiritual values, and a tolerance of all creeds and tribes [sic]" (www.artsrn.ualberta.ca).

Zanzibar was unarguably chosen, Joseph Anene notes, because of the favourable climatic condition unlike the torrid heat in Muscat, deep and spacious harbour (444) and the relative peace in the area (Imbua, Onor and Odey 94). These alluring indices guided the commercial prince's activities in East Africa. Oman has maritime contiguity with East Africa. As a result of the inter-mingling along the coastlines, there was the emergence of some principal coastal towns 
International Journal of Arts and Humanities

ISSN: 2581-3102

Volume: 04, Issue: 06 "June 2020"

resplendent in Islamic architecture and trade in Kilifi, Kilwa, Lamu, Mafia, Malindi, Mozambique, Pate, Pemba, Sofala, and Zanzibar that later became the capital of Sayyid Said.

It is instructive to note that the hegemonic control of the Portuguese which sacked the city-states of Kilwa and Mombasa was possible as a result of maritime power. The emergence of Zanzibar as capital (replacing Muscat) of Sayyid Said points to two important points- the commercial acumen of the Omani Commercial Prince, Sultan Said and the commercial revolution in the East coast of Africa.

The end of hegemony and subsequent expulsion of the Portuguese from Muscat in 1650 strategically position the mercantilist and ethnic communities of Oman on the path of political and economic transformation building Oman into a commercial and maritime 'State' despite opposition and intrigue at times against Omani rulers. Yet by the late eighteenth century, there was no noticeable evidence of any Omani, that is to say Albusaidi, political domination of East Africa, one of the main traditional destinations of migrants from Oman. That there was no attempt at a systematic conquest or the establishment of an effective administration apparatus in East Africa was doubtlessly due to the inter-ethnic conflict in Oman itself. In fact, as a result of this conflict, by the latter part of the eighteenth century, the ruling branch of the Albusaidis had lost more ground at home, let alone having the will or the resources to consolidate its position overseas (Bhacker 22). In spite of these conflicts in Oman, three factors combined at the turn of the nineteenth century to encourage the Albusaidi rulers to direct their attention towards East Africa: the commercial expansion of Muscat within the Indian Ocean regional system; the identification of the interests of Omani rulers with Banyan merchant groups and the increasing forays of Westerners into the Indian Ocean area (26).

The advent of the Omani Arab hegemony was an important factor in these changes. The final expulsion by 1728 of the Portuguese, south of the Rovuma River, with the aid of the Omani, was not followed immediately by the placing of an effective, comprehensive Omani authority on the coast. At the turn of the century, the Omani presence was significantly evident in only three main centres: Mombasa, Zanzibar and Kilwa. Even in Mombasa, the Omani Mazrui family had come to assume an autonomous status which, in time, encouraged its members to demonstrate virtual defiance of the Busa'idi dynasty ruling in Muscat (Salim 211).

\section{OMANI INCURSION AND THE IMPACT ON THE DEVELOPMENT OF EAST AFRICA}

Historically members of merchant communities, having contacts at various points in the Indian Ocean trading region, had, for a variety of commercial, religious and political reasons, moved from environments where they had been relatively disadvantaged to ones where they were more favourably treated (Chaudhuri; Martins in Bhacker 68). In nineteenth century East Africa many 
International Journal of Arts and Humanities

ISSN: 2581-3102

Volume: 04, Issue: 06 "June 2020"

traders in Zanzibar were Omani Arabs, some of whom having chosen to migrate in order to join their ' co-nationals', already settled in Africa since at least the expansionist era of the Ya'ariba. Like their predecessors, these later arrivals were with time integrated, either wholly or partially, within the expanding 'Swahili' community (Bhacker 68).

Bhacker Reda's study on the Omani provides three interesting themes that shaped their history. He notes,

Maritime trade, Imamate Government and tribalism are three of the most pervasive themes in the history of Oman. Whilst the outlines of the Omani tribal structure, like those of long-distance commerce, antedate the advent of Islam, the final form of tribalism has been strongly influenced by the political dimensions of the Imamate Government following the rise of Islam. Thus, of the three abovecited themes, maritime trade has been the most persistent and resilient and has had a more lasting impact than the other two as a unifying economic and cultural force for the people of Oman (xxiv).

The role of geography has significantly influenced the economic, cultural and political spheres of the Omani. The presence of navigable rivers and vessels predisposed the traders into longdistance commerce to other lands where there proselytized their Islamic faith, culture and assert political hegemony.

Recent archaeological evidence puts back the origins of the impact of maritime trade on Oman to as early as the sixth millenium BC when parts of Oman are thought to have established commercial exchange links with the coastal inhabitants of the area known by the Greeks as the Erythraean Sea (cited in Bhacker xxiv). This area included the borderlands of the Arabian Sea and its two extensions of the Red Sea and the Gulf which penetrate the Afro-Asian land mass. During the Islamic era, the effect of maritime trade was such that the Ibadi religious-cum-tribal structure which gave rise to the Imamate Government could not have implanted its roots in Oman had it not, in its initial phases, received financial support from Oman's mercantile communities.

Being by nature a long-distance phenomenon, maritime trade bridges geographical and cultural boundaries and criss-crosses established commercial networks and political frontiers. In this phenomenon, Omani ports, forming part of the Indian Ocean region, have played a fluctuating comercial and political role on a local, regional or global scale depending on Oman's own political condition and its interaction with internal and external influences (xxiv).

The choice of Zanzibar, Kilwa, Mombasa, Pemba and other coastal city-states by Oman was majorly economical. In the first half of the nineteenth century the continuing rise in demand for 
International Journal of Arts and Humanities

ISSN: 2581-3102

Volume: 04, Issue: 06 "June 2020"

ivory in India, Europe and the United States of America; the expansion from the second decade onwards of the slave trade with slaves destined for both the local plantation economy and export; and the decline in the price of the leading imports, cotton goods, all contributed to make the terms of trade very lucrative on the East African coast (Bhacker 64).

Nevertheless, to actualize this motive, Said conjured socio-cultural and political under-current. The roots for the growth of a commercial empire penetrating the interior of East Africa were also laid in the early part of the nineteenth century. By the 1840s the trade in ivory and slaves was expanding rapidly and was drawing the interior into the trading network already established on the coast. Kimambo has queried the exaggerated nexus between ivory trade and the slave trade.

There is a tendency to consider ivory and slaves as interconnected commodities of trade since in most cases they came from the same region and also since slaves could be employed to carry ivory. But the importance of this superficial interrelationship has been exaggerated. Clearly, for long-distance trade, both ivory and slaves had to be exchanged for other bulky commodities, such as cloth, wire and beads which also had to be transported. A much more important inter-relationship centres on the fact that both commodities were involved in an international commercial system that was drawing East Africa into a subordinate role, and in turn influencing the development of trade in East Africa in the period prior to the establishment of colonialism. The fact is that East Africa was already drawn into the capitalist economic system prior to the actual establishment of colonial rule (234-235).

The viability of trade and other ancillary activities on the coast was principally determined by the geography of the area. Initially, commercial intercourse was restricted to the coastline, a development that was exclusive to the Arabs. Thus, commerce and religion flourished due to the influence of geography.

The great transformation of Africa's economic relations with the wider world did not occur with the late nineteenth century partition by European powers (Wallerstein 23). There had long been trading networks in various parts of Africa, and many of these networks had extended beyond the frontiers of the African continent - across the Indian Ocean, the Mediterranean, and the Atlantic. The Omani traders had slaves, cloves, spices, and ivory as merchandize.

These Arabic traders through Sultan Said knew the importance of establishing plantations with the availability of slaves in the interior, irrespective of the British abolitionist position. By the time Sayyid Said had transferred his economic interest to East Africa, the slave traffic to Mauritius had been reduced by British intervention and the island had even been taken over by them in 1810. But Sayyid Said encouraged the expansion of clove and coconut plantations in 
International Journal of Arts and Humanities

ISSN: 2581-3102

Volume: 04, Issue: 06 "June 2020"

Zanzibar and Pemba. By the time he transferred his capital to Zanzibar in the 1840s, clove plantations were already the dominant economic activity and were mostly operated by slave labour. This created a class of landowners, originally mainly Arabs, but by the 1860s including indigenous Shirazi and Indians as well. By the 1860s it is estimated that the islands of Zanzibar and Pemba were absorbing about 10000 slaves per annum. This was in addition to those supplied to other markets (largely Arab) abroad. It has been estimated that by the 1860s the Zanzibar market alone was handling as many as 70000 slaves per annum and that the heaviest traffic started after 1840 (cited in Kimambo 235). Although, these figures may have been greatly exaggerated, they do indicate that the slave trade has increased tremendously by the middle of the nineteenth century (Kimambo 235).

Having consolidated their presence in the East coast of Africa, the Arabs made inroads into the interior for trading activities. The long-distance trade was sustainable because of the availability of ivory and slaves. Contending from an Afrocentric perspective, Kimambo argues that,

Clearly, the terms of long-distance trade in both ivory and slaves were quite favourable to those involved in exploiting the commodities. Consequently, longdistance trade routes radiated from the coastal towns (such as Kilwa, Bagamoyo, Pangani, Tanga and Mombasa) to various points in the interior. As a result, by the 1870s most of present-day Tanzania, Kenya, Uganda, eastern Zaire, northern Zambia, Malawi and northern Mozambique had become part of a vast hinterland connected with Zanzibar through these coastal towns and therefore integrated to varying degrees into the international trading network (237).

Aggregating the African view on alien incursion in the economic affairs of Africans, the indigenes were helpless and manipulated by the invading traders whose utter disregards for the indigenous people was expressed in objectifying them and reckless exploitation of the resources. Nevertheless, the penetration into the interior increased the production of cash crops like cloves which Zanzibar is reputed to produce three quarters of the world's supply of clove (Oliver and Fage 171), food crops like maize and rice which later became popular staples and sources of revenue to the farmers and traders. However, the indigenous population in this commercial exchange were unequal partners whose participation in the trade were on dictated terms from the Arabs and other foreigners. Philip Curtin attempts an estimation of the impact of trade on the East Africans by comparing the Senegambian experience thus,

The data are easily accurate enough to support the generalization that, in spite of the probability of strong contrary swings in wartime, the net barter terms of trade shifted consistently in favor of Senegambia over a period of nearly two centuries. Even if the accuracy of the estimates is no closer to reality than half or double, the 
International Journal of Arts and Humanities

ISSN: 2581-3102

Volume: 04, Issue: 06 "June 2020"

overall shift to Senegambia's advantage from the 1680's to the 1830's would have been within the range of fivefold to twentyfold. Or, as a median estimate, the Senegambians at the end of the period received about ten times as much as they had received 150 years earlier for the same quantity of goods exported (340).

While the Senegambians were lucky with statistical data on the effect of trade on East Africa. However, R. Coupland provides a scintilla of statistics for Zanzibar and some coastal cities, was able to show, for example, that by 1876 Kilwa was making $£ 120000$ profit yearly, and that between 1869 and 1876 customs revenue in Zanzibar had risen from $£ 65000$ to over $£ 100000$ per annum (cited in Kimambo 237).

The presence of the Arab traders in the interior opened up plantations, introduced some crops, the socio-political structure of the indigenous population was interfered with by stratifying the population into classes- privileged elite and the peasant. The former comprised the Sultan Sayyid and his Arab compatriots while the latter were the indigenous peasants who worked the plantations owned by the former. This socio-economic and political stratification led to the emergence of the minority issue in East Africa- where the fate of the increasing indigenous peasant population is determined by the economically buoyant Arab elite minorities. In order to consolidate Said's economic control of the east coast of Africa, he meddled in the internal politics of the time. The succession intrigues that engulfed Lau and Pate were reference points. Said desire the imposition of a protégé against the wish of the Mazrui of Mombasa. This led to a pact between the sovereign of Mombasa and Britain on the one hand and Said and the British on the other. The Afro (Mombasa)-Anglo pact was intended to shield the Africans from the invading Said while the Arab-Anglo treaty was to use Said to boost the British anti-slavery campaign in East Africa.

To boost investment capital, Sayyid Said invited Indian financiers to provide credit facilities to Arab investors who were associates of the commercial prince. This investment promotion scheme was exclusive to the Arabs as Africans formed the exploited component in the Afro-Arab economy. This was a deliberate ploy to retard the East Africans economy perpetually by forbidding them access to credit and consign their economy to raw material production and provision of labour. Sayyid Said pulled a diplomatic string to mend the unsavoury Arab-Indian relations by inviting the Indians to fill the gaps created by Arab incompetence in financial matters. Thus, while the Indians provided financial services the Arabs managed the caravans that penetrated the interior for trading activities. It is worthy of note that the abolition of slavery and the slave trade in the east coast of Africa did not guarantee social mobility. While the socioeconomic gaps widened due to the swelling population of the poor indigenous peasants, the seed of discord and subsequent revolution was sown (Imbua, Onor and Odey 94). 
International Journal of Arts and Humanities

ISSN: 2581-3102

Volume: 04, Issue: 06 "June 2020"

The influx of people into the commercial cities because of trade necessarily require security. Sayyid Said established maritime control of the coastal trade routes and harbours with a strong naval force from Muscat. There was the unification of customs and sundry duties, and currency regimes in the coastal areas. This innovation removed the restrictions having discriminatory duties and different currencies as was the earlier practice. Hence, the uniformed duty of $5 \%$ payment in copper coin imported from India was enforced (94).

The cultural impact represented by the spread of Islam and more significantly by the spread of the Swahili (culture) and Kiswahili (language) is commendable. Linguistically, the inter-racial interactions along the coastline result in the creation of Swahili which became a language of instruction and commerce. Swahili assumes a linguistic unity from the beginning of the Contemporary Era with a linguistic spread down the coast (oxfordre.com). From southern Somalia to northern Mozambique, speaker of Swahili were configured geographically into towns and villages that metamorphosed into city-states, "when there were major upturns in international trade and were [city-states] integrated in the wider Indian Ocean world" (oxfordre.com).

The elegant Swahili civilization gained cosmopolitanism. Sheriff contends that transformation of these coastal areas into commercial hubs the influx of people into these city-states led to the mix with other Indian Ocean languages and literature. Islam spread with trade, and mosques became a prominent part of the preserved archaeological relics along the Swahili coast. Thus, it amounts to an exercise in futility to attempt severing the various linguistic strands- "Oriental" or "African" because they are two inseparable sides of the dense cultural fabric of the littoral people (oxfordre.com).

Al-Mughairî presents an explanation for the socio-cultural intermingling in East Africa in the form of inter-racial (Arab-Afro) and the commercial implications during the $19^{\text {th }}$ century, 'nobody could tell the difference between an Arab and a Zinji [negro]' (Juhaina; Tolmacheva in Bhacker 68). The serenity and friendliness on along the coast pulled other traders into East Africa from India, migrating to Zanzibar either directly or after long or short periods of residence in Muscat or in other Omani ports. These latter also, in time, became more or less 'swahilised' (Emery in Bhacker 68). Perhaps the most striking point to note is that the Omani ruler, Said b Sultan, treated all traders migrating to Africa from Oman as 'natives of Oman'. All these 'natives', including the Indians but excluding any Western merchants residing in East African ports, were allowed to participate in the trade of the African mainland. Sheriff captures the situation thus, "This was the most guarded privilege granted to native traders and formed a corner stone on which Omani commercial empire was constructed" (Sheriff 114). Had the 'Indians' from Oman been regarded by contemporary Omani rulers as 'foreigners', they too, like the Westerners, would have been excluded from the mainland (Bhacker 68). Due to interactions 
International Journal of Arts and Humanities

ISSN: 2581-3102

Volume: 04, Issue: 06 "June 2020"

on the coastline the Indians exhibited fluency in Swahili. Some of the speakers of this linguistic innovation could barely speak or write Arabic. Therefore, Swahili became a unifying tongue that wove the different races on the coast of East Africa or Swahili belt.

\section{CONCLUSION}

The geography of East Africa is serene, the rivers navigable and the soil fertile for agricultural activities, and reputably lucrative for trade. It is a combination of the above that pulled the Arabs, Indians and other nationalities into the East African coast. The incursion of the Omani Arabs into East Africa was in a bid to expand the commercial enterprise of the commercial prince, Sayyid Said and his cronies (fellow traders). The presence of these Arabs exerted enormous on the economic lives of the Africans. The trade in slaves, ivory, cloves, hides and skin flourished as the introduction of maize and rice into the east coast of Africa. The influx of various races in East Africa made the region cosmopolitan with the emergence of coastal citystates like Malindi, Sofia, Kilwa, Mombasa, Mozambique, Pemba, and Zanzibar. Kilwa, Mombasa and Zanzibar were prominent coastal city-states and of these three, Zanzibar is the capital of Oman that replaced Muscat. The change of capital was during the reign of Sultan Sayyid Said. There were a number of innovations that were introduced into the east coast of Africa like the introduction of customs duty, and investment capital and the Swahili/Kswahili which unified the people, indigenes and non-indigenes alike. However, it is worthy of note that the presence of the Arabs and the accompanying innovations reduced the indigenous East Africans to unequal participants in the economic, socio-cultural and political development of the region. The indigenes provided docile labour, they were enslaved, and their internal political affairs meddled into by the Sayyid Said. The yawning socio-economic gap between the indigenous African and the elitist Arabs and their cronies sowed the seed of discord that nurtured future revolution in East Africa.

\section{WORKS CITED}

Abdul, Sheriff. "The Swahili in the African and Indian Ocean Worlds to c. 1500" oxfordre.com. Accessed $31^{\text {st }}$ May, 2019.

Bhacker, M. Reda. Trade and Empire in Muscat and Zanzibar: Roots of British domination. London: Routledge, 1994.

Curtin, P. D. Economic Change in Pre-Colonial Africa: Senegambia in the Era of the Slave Trade. Madison: U W P, 1975.

Hopkins, A. G. An Economic History of West Africa. London: Longman Group Ltd., 1973. 
International Journal of Arts and Humanities

ISSN: 2581-3102

Volume: 04, Issue: 06 "June 2020"

Imbua, David L, Onor, Sandy O and Odey, Patrick O. A Companion to African History in the Nineteenth and Twentieth Centuries. Makurdi: Aboki Publishers, 2017.

Kimambo, I. N. "The East African coast and hinterland, 1845-80." In General History of Africa-VI: Africa in the Nineteenth Century until the 1880s, edited by Ade Ajayi, J. F., 234-269. Paris: United Nations Educational, Scientific and Cultural Organization, 1989.

Oliver, Roland and Fage, John D. A Short History of Africa. Baltimore: PenguinBooks Ltd., 1962.

Salim, A. I. "The East African Coast and Hinterland, 1800-45." In General History of Africa-VI: Africa in the Nineteenth Century until the 1880s, edited by Ade Ajayi, J. F., 211-233. Paris: United Nations Educational, Scientific and Cultural Organization, 1989.

Sheriff, A. M. H. 'The Rise of a Commercial Empire: An Aspect of the Economic History of Zanzibar, 1770-1873', Ph.D. Thesis, University of London, 1971.

Wallerstein, I. "Africa and the World- Economy." In General History of Africa-VI: Africa in the Nineteenth Century until the 1880s, edited by Ade Ajayi, J. F., 23-39. Paris: United Nations Educational, Scientific and Cultural Organization, 1989.

www.artsrn.ualberta.ca. Accessed $1^{\text {st }}$ June, 2019. 